\title{
Impact of Systemic Fungicides on Lesions Formed by Inoculation with the Bluestain Fungus (Ophiostoma minus) in Loblolly Pine (Pinus taeda L.)
}

\author{
Joseph J. Doccola, Brian L. Strom, Cavell Brownie, and Kier D. Klepzig
}

\begin{abstract}
Ophiostomatoid fungi are important components within the highly damaging insect-fungal complexes attacking trees in North America. This group includes the disease agents responsible for Dutch elm disease and laurel wilt, as well as a number of associates of tree-killing bark beetles. While systemic fungicides have been applied against ophiostomatoids in certain fungus-host systems, the breadth of their utility and their management implications for a wide array of fungus and host species remain uncertain. To evaluate the impact of commercially available fungicides against the bluestaining fungus Ophiostoma minus, an associate of the southern pine beetle, researchers conducted two experiments with loblolly pines (Pinus taeda; mean dbh 14.2 and $18.5 \mathrm{~cm}$, respectively) in central Louisiana, U.S. The first experiment screened three fungicides (Alamo ${ }^{\circledR}$, Arbotect ${ }^{\circledR} 20$-S, and PHOSPHO-jet) for their systemic impacts on $O$. minus, and the second further evaluated the best performing product (Alamo) alone and in combination with Arbotect 20-S. In all cases, loblolly pines were stem-injected basally and challenged with inoculations of cultured O. minus at time periods ranging from 28 days to 738 days post-treatment. In both experiments, treatment of loblolly pines with Alamo produced the smallest lesion areas, indicating that this treatment was the most effective for limiting the within-tree growth of $O$. minus. This effect was still present more than two years post-treatment. The study authors conclude that Alamo is the most effective product of those evaluated for prophylactic treatment against $O$. minus, and suggest that evidence is building for the effectiveness of this product generally against ophiostomatoid fungi.

Key Words. Dendroctonus frontalis; Scolytidae; Propiconazole; Southern Pine Beetle; Systemic Injection; Vascular Wilt.
\end{abstract}

Insects and disease agents commonly act in concert to cause plant injury. Scolytid bark beetles (Coleoptera: Curculionidae: Scolytinae) are frequently associated with fungi that are carried on specialized body structures (mycangia) and/or on the surface of their bodies. Bark beetles attack their host, especially conifers (family Pinaceae), by boring through the outer bark and constructing egg galleries in the inner bark (phloem). During the attack process, vascular tissues of host trees are inoculated with beetle-associated fungi and, depending upon the species involved, plant decline and death may be attributable to the beetle, fungus, or both. For example, the establishment of the fungus may contribute to host tree mortality by producing toxins, either by mycelial penetration of tissues or by interaction with tree defense responses (Paine et al. 1997). It is a primary goal of pest management to provide resource protection under all of these scenarios.

Systemic fungicides can be effective against bluestain fungi, such as Raffaelea spp. in redbay (Mayfield et. al. 2008), Ophiostoma novo-ulmi in American elm (Haugen and Stennes 1999), and Ceratocystis fagacearum in live oak (Wilson and Lester 1995), by reducing lesion formation and favoring tree survival. These organisms cause vascular wilt by occluding the conductive tissues in their host species, often resulting in tree mortality. Loblolly pine (Pinus taeda L.) is inoculated with the bluestain fungus Ophiostoma minus (Hedgcock) Sydow \& P. Sydow upon attack by the southern pine beetle, Dendroctonus frontalis Zimmermann (Clarke and Nowak 2009). Although the community interactions that occur beneath the bark may be quite complex (involving many species of fungi, mites, and bacteria), the result of a southern pine beetle attack is that the host tree is inoculated with $O$. minus, which affects tree tissues, the bark beetle colonization process, and ultimately tree death.

The role of systemically injected insecticides has been recently investigated for efficacy against bark beetles (Grosman and Upton 2006; Grosman et al. 2009; Grosman et al. 2010), but results have varied. Efficacy of emamectin benzoate formulations (Syngenta Crop Protection) was reported against southern pine beetles and ips engraver beetles (Grosman et al. 2009). Adult gallery construction, brood development, and emergence were all significantly reduced. However, a number of trees were killed, and because adult beetles tunnel in the phloem before ingesting insecticide, the beetles inoculate the tree with various fungi, including bluestains. This leads to uncertainty as to whether mixed treatments (fungicides and insecticides) may improve effectiveness.

The objective of this study was to evaluate the effectiveness of systemic fungicides for reducing the size of lesions formed in loblolly pine following inoculation with $O$. minus. Although the bark beetle is believed to be the primary agent of mortality in this system, it is uncertain whether management of the fungal associates can assist in tree protection or, at least, minimize the negative effects of bluestain on wood quality. It is also of 
interest to increase our knowledge about the breadth of impacts that systemic fungicides may have. Two experiments were conducted, the first to screen three products for their systemic activity against $O$. minus in loblolly pine, and the second to more rigorously assess the most effective product when applied alone and in combination. The three fungicides selected were Alamo $^{\circledR}$ (14.3\% Propiconazole w/w, Syngenta Crop Protection, LLC, Greensboro, North Carolina, U.S.), Arbotect $^{\circledR}$ 20-S (20\% 2-(4-thiazolyl) benzimidazole w/w, Syngenta Crop Protection, LLC, Greensboro, North Carolina, U.S.), and PHOSPHO-jet (45.8\% Mono-and di-potassium salts of phosphorous acid w/w, Arborjet, Inc., Woburn, Massachusetts, U.S.).

\section{METHODS}

In both experiments, treatments were assigned in a completely randomized design to loblolly pines growing in central Louisiana (Winn Ranger District, Kisatchie National Forest). Researchers injected each selected tree around its base with the systemic fungicide using the Tree I.V. system and Arborplugs ${ }^{\mathrm{TM}}$ (Arborjet, Inc. Woburn, Massachusetts, U.S.), with an injection point targeted at every $10 \mathrm{~cm}$ basal circumference. It was assumed that fungal inoculations within a tree were independent (Klepzig et al. 2005), which allowed for multiple sample periods over time (Figure 1; Figure 2). In both experiments, untreated trees were drilled and Arborplugs installed so that stem injury could be simulated and any effects on tree responses evaluated against treatments.

The size of lesion area produced around each point inoculation of $O$. minus was the primary response variable; standard methods were employed to inoculate and measure lesions (Klepzig et al. 2005; Klepzig and Strom 2011). At each sample period, lesions were measured approximately one month after inoculations were made at breast height $(+/-1 \mathrm{~m})$. Inoculations required of the removal of a bark plug, $1.27 \mathrm{~cm}$ diameter, to expose the sap-

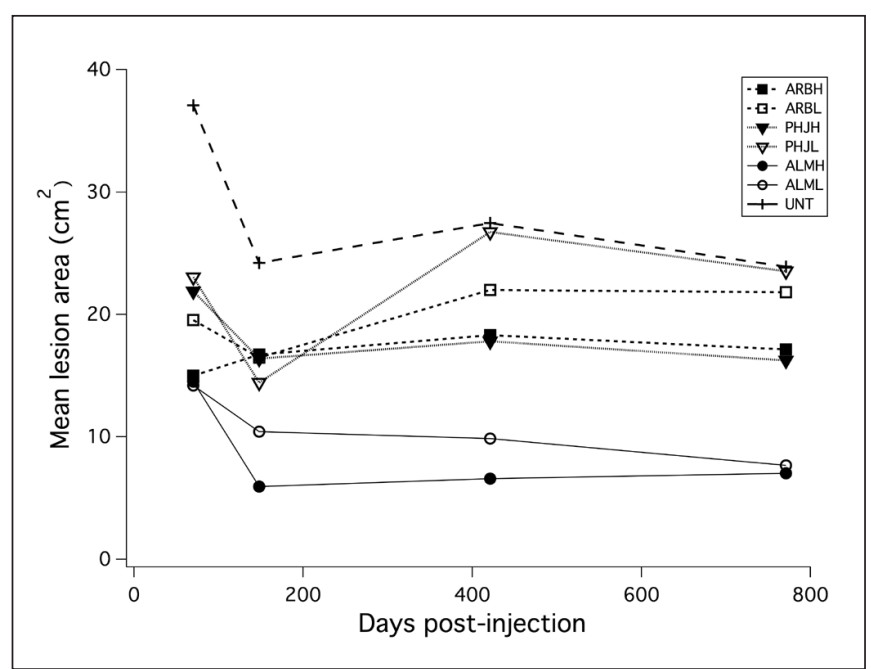

Figure 1. Mean lesion areas $\left(\mathrm{cm}^{2}\right)$ resulting from single point inoculations with the bluestaining fungus, Ophiostoma minus, into loblolly pines in central Louisiana. Trees were injected with one of three products $(\mathrm{ARB}=$ Arbotect $20-\mathrm{S}, \mathrm{PHJ}=\mathrm{PHOSPHO}-\mathrm{jet}, \mathrm{ALM}$ $=$ Alamo $)$ at one of two doses $(\mathrm{L}=$ low, $\mathrm{H}=$ high) or left untreated. Lesions were determined from destructive sampling of bole tissue approximately 30 days following inoculation with 0 . minus on 2-4 sides of each tree. Injections with fungicide products were made on May 6-7, 2008. wood face, which then received a single $0.5 \mathrm{~cm}$ plug of malt agar with $O$. minus. The $O$. minus was freshly isolated and cultured from living southern pine beetles collected on the Homochitto National Forest (Mississippi, U.S.). Once the O. minus was in place, the bark plug was replaced, securing the $O$. minus against the sapwood and promoting more natural conditions for fungal growth. For measurement of lesion size, bark was removed to expose the underlying lesion and the outer boundary of the lesion traced onto a sheet of transparent film. Lesion area (square centimeters) was determined in the laboratory by tracing the outlined area with a digital planimeter (Lasico model no. 1281-12).

\section{Experiment}

Three systemic fungicide products were applied to loblolly pines by stem-injection to assess for activity against $O$. minus: PHOSPHO-jet (45.8\% Mono-and di-potassium salts of Phosphorous Acid), Alamo (14.3\% Propiconazole), and Arbotect 20-S (20\% 2-(4-thiazolyl) benzimidazole). Treatments were applied on May 6-7, 2008 to loblolly pines near Williana, Louisiana, U.S. (N3145'25.6”, W092 36'38.4”). This initial experiment was primarily a screening of the products, leading to two dosages for each product and giving seven treatments, each replicated four times (four trees per treatment). PHOSPHO-jet was applied at 5 and $10 \mathrm{~mL}$ per $2.5 \mathrm{~cm} \mathrm{dbh}$, Alamo was applied at 10 and $20 \mathrm{~mL}$ per $2.5 \mathrm{~cm} \mathrm{dbh}$, and Arbotect 20-S was applied at 3 and $6 \mathrm{~mL}$ per $2.5 \mathrm{~cm} \mathrm{dbh}$. These rates equate to 1 to $2 \times$ the label rate for PHOSPHO-jet; $1 \mathrm{x}$ the label and maximum therapeutic rate (of $2 \times$ ) for Alamo; and 0.5 to $1 \times$ the Arbotect label rate. The lower rate for Arbotect was selected due to concerns with possible phytotoxicity. Each was diluted with water $(3,4$, and 33 volumes for

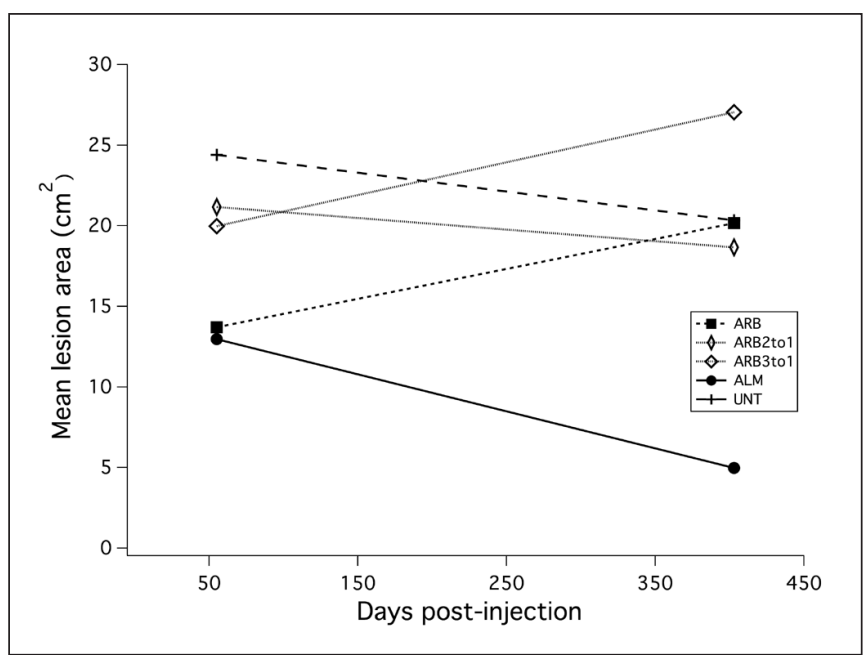

Figure 2. Mean lesion areas $\left(\mathrm{cm}^{2}\right)$ resulting from single point inoculations with the bluestaining fungus, Ophiostoma minus, into loblolly pines in central Louisiana in the second experiment. Trees were injected with one of two products (ARB = Arbotect 20-S, ALM = Alamo) either alone or with a mixture (2:1 Arbotect to Alamo [ARB2to1] or 3:1 Arbotect to Alamo [ARB3to1]) or untreated (UNT). Lesions were determined from destructive sampling of bole tissue approximately $\mathbf{3 0}$ days following inoculation with 0 . minus on two sides of each tree. Injections with fungicide products were made on May 4-7, 2009. 
Alamo, PHOSPHO-jet, and Arbotect, respectively) at the time of application. Tree diameters at breast height averaged $14.2 \pm 0.2 \mathrm{~cm}$, which led to an average injected volume (for low and high doses, respectively) of: 140 and $280 \mathrm{mLs}$ of PHOSPHO-jet, 224 and $448 \mathrm{~mL}$ of Alamo, and 577 and 594 $\mathrm{mL}$ of Arbotect 20-S. Thus 28 to $56 \mathrm{~mL}$ of PHOSPHO-jet, 56 to $112 \mathrm{~mL}$ of Alamo, and 17 to $34 \mathrm{~mL}$ of Arbotect formulations were applied for low and high doses, respectively.

Trees were inoculated with $O$. minus four times: $30,112,391$, and 738 days after treatment with fungicides (Figure 1). Lesion areas at the points of inoculation were determined $\sim 30$ days after inoculation. At each sampling period, two subsamples were measured per tree, except for 112 days when four subsamples were measured per tree. Each inoculation point of $O$. minus provided one subsample; tree means were used for all evaluations.

\section{Experiment}

Results from the 2008 screening experiment suggested that Alamo was the most effective formulation (Figure 1), so 2009 treatments emphasized this product. Arbotect $20-\mathrm{S}$ was used at a rate below the maximum label rate $(72 \mathrm{~mL}$ per $2.5 \mathrm{~cm} \mathrm{dbh}$ ) in the first experiment. Researchers chose to combine the two formulations in this experiment in an effort to improve systemic activity and to reduce the viscosity [of $56 \mathrm{mPas}$ (millipascal seconds) @22C] of the Alamo formulation for easier application (Alamo MSDS). These objectives required that products be mixed, necessitating some applications that were off-label. Five treatments were assigned to an experimental population of 50 loblolly pines (N31 ${ }^{\circ} 49^{\prime} 08.9^{\prime \prime}$, W092 $\left.32^{\circ} 01.7^{\prime \prime}\right)$, providing 10 replicate trees per treatment. Treatments were applied over a four-day period (May 4-7, 2009).

In 2009, treatments were applied at $100 \mathrm{~mL}$ total volume; the amount of each ingredient varied by the ratio of the treatment. Trees averaged $18.5 \pm 0.25 \mathrm{~cm}$ dbh. The Alamo-only dose per tree was $100 \mathrm{~mL}$, which was $\sim 13 \mathrm{~mL}$ per $2.5 \mathrm{~cm}$ dbh, $3 \mathrm{~mL}$ higher than applied in 2008 and closer to the therapeutic label rate (10-20 mL per $2.5 \mathrm{~cm})$. The Arbotect 20-S-only treatment was also $100 \mathrm{~mL}$, or $\sim 13 \mathrm{~mL}$, per $2.5 \mathrm{~cm}$ dbh. This was $8 \mathrm{~mL}$ more than in 2008 and closer to its therapeutic label rate $(12-24 \mathrm{~mL}$ per $2.5 \mathrm{~cm} \mathrm{dbh})$. To determine if a mixture of these two products was more effective than each fungicide individually, two ratios (2:1 and 3:1, Arbotect to Alamo) were compared. The 2:1 ratio treatment was prepared by mixing $67 \%$ Arbotect to $33 \%$ Alamo v/v, and the $3: 1$ ratio treatment was prepared by mixing $75 \%$ Arbotect to $25 \%$ Alamo v/v. In both cases, trees injected with a ratio treatment received $\sim 13 \mathrm{~mL}$ per $2.5 \mathrm{~cm}$ dbh for a $100 \mathrm{~mL}$ total per tree.

Inoculations with $O$. minus were made 28 days and 373 days post treatment, and lesion areas determined about 30 days later following the procedures from 2008.

\section{Statistical Analysis}

Although individual inoculations were evaluated only once due to the destructive nature of the sampling procedure, it was expected that responses (lesion areas) on a given tree may be correlated in time. This led to a repeated measures analysis for evaluating impact of the fungicides on lesion area for the 2008 data, where evaluations were made over four periods. In this analysis, fungicide treatment (with seven categories) was regarded as the between-subject factor, and time period (with four levels) was the within-subject factor. Following a non-significant test result for sphericity $(\mathrm{P}=0.10)$, split-plot $\mathrm{F}$-tests (univariate repeated measures) were reported for fungicide treatment and time period main effects, and treatment $\times$ time period interaction. Because the goal was to identify the best fungicide treatment(s), and Alamo strongly met this criterion (Figure 1), detailed examination of the treatment $\times$ time period interactions provided little information of practical importance and was not pursued in the 2008 data. Individual contrasts were performed on treatment means (averaged over periods) to test for rate and rate $\times$ fungicide effects, and to carry out pairwise comparisons among fungicides averaged over rates. To maintain an experiment-wide alpha level of 0.05 , a Bonferroni correction was applied to the pairwise comparisons among fungicide treatments (including the control, there were six comparisons resulting in a critical $P$-value of 0.0083 ).

Trees injected with fungicides in 2009 were evaluated for lesion areas twice, and a split-plot analysis was performed to test for fungicide treatment, time period, and treatment $\times$ time period effects. A strong treatment $\times$ time period interaction led to separate comparisons among treatments at each time. The effect of fungicide treatment was significant at each time period; Tukey's Honestly Significant Difference (HSD) range test was applied to evaluate relationships among treatment means. Prior to all analyses, lesion areas were square root transformed, then averaged for each tree at each sampling period to better meet the assumptions of parametric statistics for distribution and variance. Statistical analyses were conducted using a combination of SAS (V. 9.2) and JMP (V. 9) (SAS, Inc., Cary, North Carolina, U.S.) with significance being accepted when $P<0.05$.

\section{RESULTS}

\section{Experiment}

Trees were evaluated for crown fade (phytotoxicity) on June 5, 2008; June 20, 2008; and July 28, 2008, which were 30, 45, and 83 days post-treatment. At 30 days, all four trees treated with PHOSPHO-jet high and two of the four trees treated with PHOSPHO-jet low exhibited reddish or browning crowns. After 45 days, there was little change but by day 83 post-injection tree canopies were mostly recovered with only two (both PHOSPHO-jet high) having any noticeable crown discoloration. Trees treated with Alamo and Arbotect did not exhibit any noticeable crown discoloration. The study's researchers did not observe any mortality of treated trees.

The repeated measures analysis produced significant treatment ( $=$ fungicide product) and time period effects $(\mathrm{F}=10.21$, $\mathrm{DF}=6,21, P<0.001$ and $\mathrm{F}=7.38, \mathrm{DF}=3,63, P<0.001$, respectively) and a non-significant treatment $\times$ time period interaction $(\mathrm{F}=1.57, \mathrm{DF}=18,63, P=0.096)$. Rate and rate $\times$ fungicide (averaged over period were non-significant $(\mathrm{F}=3.13$, $\mathrm{DF}=1,21, P=0.091$ and $\mathrm{F}=0.01, \mathrm{DF}=2,21, P=0.994$, respectively). Contrasts among fungicides, averaging over time periods, revealed that treatment with Alamo or Arbotect 20-S significantly reduced lesion areas produced in response to inoculation with $O$. minus (adjusted critical $P$-value $<0.0083$; six pairwise comparisons were made among the untreated and the three products averaged across rates). Alamo was also significantly more effective than both Arbotect 20-S and PHOSPHOjet $(P<0.0001$ in each case), which did not differ from each other $(P=0.51)$. Mean lesion size in trees treated with PHOSPHO-jet was not different than in untreated trees $(P=0.02)$.

(02011 International Society of Arboriculture 


\section{Experiment}

Because no crown discoloration was observed in 2008 with Alamo or Arbotect 20-S, tree crowns were only evaluated for discoloration at the time of first inoculation with $O$. minus (28 days post-treatment); no discoloration was observed.

The fungicide treatment main effect and the treatment $\times$ time period interaction were highly significant $(F=9.80$, DF $=4,45, P<0.001$ and $\mathrm{F}=7.83$, DF $=4,45, P<0.001$, respectively), leading to further comparisons among treatments being carried out separately by time period. Trees treated with Alamo produced the smallest lesions at both time periods. At the first time period, untreated trees produced the largest lesions, followed in order by the 2:1 (Arbotect 20-S:Alamo v/v mixture), the 3:1 mixture, Arbotect 20-S, and Alamo. Only Alamo was significantly different from the untreated trees, and no other difference among treatments was significant (Figure 2). At the second time period, which was more than one year after tree injections, Alamo was again the best treatment and at this date was significantly better than any other treatment (Figure 2). No other treatment differed from untreated trees at the second time period. This result supports the findings of the 2008 experiment, where the impact of Alamo was still observed in the final sample period, more than two years after treatment.

\section{DISCUSSION}

The objective of this study was to evaluate the effectiveness of systemic fungicides against the bluestain fungus, Ophiostoma minus, in loblolly pine. Alamo was clearly the most effective treatment, and attempts to improve its activity through mixing with Arbotect 20 -S were ineffective despite the reduced viscosity of the mixture. The results support the findings of other researchers, who have deployed Alamo against bluestaining fungi [e.g., laurel wilt (Mayfield et al. 2008)], and suggest that this product has a wide breadth of activity against these fungi.

Although the southern pine beetle is thought to be a primary agent of mortality, it is uncertain whether management of the fungal associates can assist in tree protection. The relationship of the characteristic blue stain in the sapwood and etiology of bluestain disease in conifers has been a question of much debate (Ayer et al. 1986; Paine et al. 1997; Klepzig et al. 2005; Six and Wingfield 2011). Even when bluestaining fungi do not cause conifer mortality, they have deleterious effects on the remaining wood and may prevent the recovery of incompletely attacked (insecticide treated) trees. The control of beetle-associated fungal growth thus remains important regardless of the ultimate cause of tree mortality. This study suggests that fungicides may have a role to play in this type of tree protection and that Alamo is the most effective product of those evaluated. It was the best fungicide in these experiments for prophylactic treatment against $O$. minus, and the study authors believe evidence is building for the effectiveness of this product generally against ophiostomatoid fungi.

These studies may be useful to the arborist in the management of vascular wilt disease in coniferous trees, for examples, 1) that systemic applications may play a role in the protection of susceptible trees, 2) injection of systemic fungicides into the restrictive vascular system (tracheids) of conifers is possible using a pressurized system such as the Tree I.V., 3) the systemic fungicide, Alamo, is effective in limiting ophiostomatoid lesions (as applied, prior to infection), and 4) that activity of the fungicide was observed for more than two years, suggesting that the need to reapply may be likewise extended to that interval.

Acknowledgments. We thank B. Parpart, J. Parpart, S. Walters, and L. Reed (USDA Forest Service, Southern Research Station, Pineville, Louisiana, U.S.) for technical assistance in all facets of the study. J. Mahfouz provided $O$. minus cultures, assisted with inoculations and subsequent data collection, and provided training on related methods. Funding for this study was provided by Arborjet, Inc. and the USDA Forest Service, Southern Research Station, RWU-4552. We thank the Winn Ranger District (Kisatchie National Forest), in particular Chad Knight, for assistance with site selection and use. We thank Dr. David Cox, Syngenta Crop Protection, LLC,. for his review and comments. Any use of trade, product, or firm names is for descriptive purposes only and does not imply endorsement by the United States Government.

\section{LITERATURE CITED}

Alamo Fungicide. Material Safety Data Sheet. Syngenta Crop Protection. Canada, Inc.

Ayer, W.A., L.M. Browne, M.-C. Feng, H. Orzanska, and H. SadeeiGhomi. 1986. The chemistry of the blue stain fungi. Part 1. Some metabolites of Ceratocystis species associated with mountain pine beetle infected lodgepole pine. Canadian Journal of Chemistry 64:904-909.

Clarke, S.R., and J.T. Nowak. 2009. Revised. Southern pine beetle. Forest Insect \& Disease Leaflet 49. US Department of Agriculture, Forest Service. Pacific Northwest Region (R6). Portland, Oregon. 8 pp.

Grosman, D.M., and W.W. Upton. 2006. Efficacy of systemic insecticides for protection of loblolly pine against southern pine engraver beetles (Coleoptera: Curculionidae: Scolytinae) and wood borers (Coleoptera: Cerambycidae). Journal of Economic Entomology 99(1):94-101.

Grosman, D.M., C.J. Fettig, C.L. Jorgensen, and A.S. Munson. 2010. Effectiveness of two systemic insecticides for protecting western conifers from mortality due to bark beetle attack. West. Journal of Applied Forestry 25(4):181-185.

Grosman, D.M., S.R. Clarke, and W.W. Upton. 2009. Efficacy of two systemic insecticides injected into loblolly pine for protection against southern pine bark beetles. Journal of Economic Entomology 102(3):1062-1069.

Haugen, L., and M. Stennes. 1999. Fungicide injection to control Dutch elm disease: understanding the options. Plant Diagnostics Quarterly 20(2):29-38.

Klepzig, K.D., and B.L. Strom. 2011. Effects of a commercial chitosan formulation on bark beetle (Coleoptera: Curculionidae) resistance parameters in loblolly pine. Journal of Entomological Science 46:124-134.

Klepzig, K.D., D.J. Robison, G. Fowler, P.R. Minchin, F.P. Hain, and H.L. Allen. 2005. Effects of mass inoculation on induced oleoresin response in intensively managed loblolly pine. Tree Physiology 25:681-688.

Klepzig, K.D., J.C. Moser, F.J. Lombardero, R.W. Hofstetter, and M.P. Ayres. 2001. Symbiosis and competition: complex interactions among beetles, fungi, and mites. Symbiosis 30:83-96.

Mayfield, A.E., III, E.L. Barnard, J.A. Smith, S.C. Bernick, J.M. Eickwort, and T.J. Dreaden. 2008. Effect of propiconazole on laurel wilt disease development in redbay trees and on the pathogen in vitro. Arboriculture \& Urban Forestry 34(5):317-324.

Paine, T.D., K.F. Raffa, and T.C. Harrington. 1997. Interactions among scolytid bark beetles, their associated fungi, and live host conifers. Annual Review of Entomology 42:179-206. 
Six, D.L., and M.J. Wingfield. 2011. The role of phytopathogenicity in bark beetle-fungus symbioses: a challenge to the classic paradigm. Annual Review of Entomology 56:255-272.

Wilson, A.D., and D.G. Lester. 1995. Evaluation of propiconazole application methods for control of oak wilt in Texas live oaks. F\&N Tests 51:389.

Joseph J. Doccola (corresponding author)

Director of Research

Arborjet, Inc.

99 Blueberry Hill Road

Woburn, MA 01801, U.S.

joedoccola@arborjet.com

Brian L. Strom

Research Entomologist

Southern Research Station

U.S. Department of Agriculture

Forest Service

2500 Shreveport Highway

Pineville, LA 71360, U.S

Cavell Brownie

Prof. Emeritus

North Carolina State University

P.O. Box 37160

Raleigh, NC 27627, U.S.

Kier D. Klepzig

Assistant Director for Research

Southern Research Station, USFS

200 WT Weaver Blvd.

Asheville, NC 28804, U.S.

Résumé. Les champignons ophiostomatales sont des composants importants au sein des complexes hautement dommageables insectes/maladies qui attaquent les arbres en Amérique du Nord. Ce groupe inclut les agents responsables de la maladie hollandaise de l'orme et de la flétrissure du laurier, tout comme un nombre associé de scolytes mortels pour les arbres. Alors que des fongicides systémiques ont été employés contre les ophiostomatales au sein de certains systèmes hôte-champignon, l'ampleur de leur utilité ainsi que les implications propres à la gestion d'une large variété de champignons et d'hôtes, demeurent incertains. Afin d'évaluer l'impact de fongicides disponibles sur le marché contre Ophiostoma mi$n u s$, un champignon associé au dendroctone des pins du Sud, deux expériences ont été menées avec des pins à encens (Pinus taeda) - DHP moyen de 14,2 à $18,5 \mathrm{~cm}$ - dans la centre de la Louisiane. La première expérience s'est faite avec trois fongicides (Alamao, Arbortect 20-S et PHOSPHO-jet) en fonction de leur impact systémique sur $O$. minus; la seconde expérience cherchait à évaluer le produit le plus performant, soit Alamo seul et une combinaison avec Arbortect 20-S. Dans toutes les situations, les pins ont été injectés au pied du tronc et ont été mis à l'épreuve avec des inoculations de culture de $O$. minus périodiquement entre 28 et 738 jours après le traitement. Dans les deux expériences, les traitements avec le Alamo ont produit les plus petites zones de lésions, ce qui indiquait que le traitement était plus efficace pour limiter le développement à l'intérieur de l'arbre de $O$. minus. Cet effet était toujours présent plus de 2 ans après le traitement. Nous en concluons que le Alamo est le produit le plus efficace de ceux évalués pour un traitement prophylactique contre $O$. minus, ce qui laisse dès lors suggérer que des preuves se mettent en place à propos de l'efficacité de ce produit contre les opiostomatales en général.
Zusammenfassung. Ophiostomatoide Fungi sind wichtige Komponenten innerhalb der hochgradig schädigenden Insekten/Pilz-Komplexe, welche die Bäume in Nordamerika attackieren. Diese Gruppe schließt die Krankheitsfaktoren, welche für die Ulmenkrankheit und Lorbeerwelke verantwortlich sind, ebenso ein wie auch eine Anzahl von baumtötenden Borkenkäfern. Während systemische Fungizide in bestimmten Pilz-WirtSystemen gegen ophiostomatoide Fungi eingesetzt werden, bleibt doch die Bandbreite ihrer Nützlichkeit und die Implikationen auf das Management für eine breite Spanne von Pilz und Wirtsarten ungeklärt. Um den Einfluss von kommerziell erhältlichen Fungiziden gegen den bläuenden Pilz Ophiostoma minus, ein Genosse des Borkenkäfers zu bewerten, führten wir in Lousiana zwei Experimente mit Pinus taeda (durchschnittlicher BHD 14.2 bzw. $18.5 \mathrm{~cm}$ ) durch. Das erste Experiment durchleuchtete drei Fungizide (Alamo, Arbotect 20-S und PHOSPHO-jet) auf ihre systemischen Einflüsse auf $O$. minus und das zweite Experiment bewertete das am besten abschneidende Produkt (Alamo) allein und in Kombination mit Arbotect 20-S. In allen Fällen bekamen die Kiefern eine basale StammInjektion und wurden in Zeitabschnitten von 28 bis 738 Tagen nach der Behandlung mit kultiviertem $O$. minus infiziert. In beiden Experimenten produzierte die Behandlung der Kiefern mit Alamo die kleinsten erkrankten Regionen, was darauf hinweist, daß diese Behandlung den größten Effekt auf die Ausbreitung des Schaderregers O. minus innerhalb des Baumes hat. Dieser Einfluss war auch nach mehr als zwei Jahren nach der Behandlung sichtbar. Wir schließen daraus, daß Alamo von allen bewerteten Produkten das beste Produkt zur prophylaktischen Behandlung gegen $O$. minus ist und sehen als schlagenden Beweis für die Effektivität dieses Produkts im allgemeinen gegen ophiostomatoide Fungi.

Resumen. Los hongos ofiostomatoides son componentes importantes dentro de los más altamente complejos insectos-hongos que atacan a los árboles en los Estados Unidos. Este grupo incluye los agentes de enfermedades responsables de la enfermedad del olmo holandés y marchitamiento del laurel, como también un número de asociados de los escarabajos que matan a los árboles. Mientras que los fungicidas sistémicos han sido aplicados contra los ofiostomatoides en ciertos sistemas hospederos de hongos, la amplitud de su utilidad, y las implicaciones de manejo para un amplio rango de especies de hongos y hospederos, permanece incierta. Para evaluar el impacto de los fungicidas comercialmente disponibles contra el hongo teñidor de azul Ophiostoma minus, asociado con el escarabajo del pino sureño, se condujeron dos experimentos con pinus loblolly (Pinus taeda; dbh medio 14.2 y $18.5 \mathrm{~cm}$ respectivamente) en Louisiana central. El primer experimento probó tres fungicidas (Alamo, Arbotect 20-S y PHOSPHO-jet) para su impacto sistémico en $O$. minus, y el segundo evaluó el mejor producto (Alamo) solo y en combinación con Arbotect 20-S. En todos los casos los pinos loblolly fueron inyectados basalmente con inoculaciones de $O$. minus a períodos de tiempo variando de $28 \mathrm{~d}$ a $738 \mathrm{~d}$ post-tratamiento. En ambos experimentos, el tratamiento de pinos loblolly con Alamo produjeron las áreas de lesión más pequeñas, indicando que este tratamiento fue el más efectivo para limitar el crecimiento de $O$. minus. Este efecto estuvo presente aún más de 2 años post-tratatamiento. Se concluye que Alamo es el producto más efectivo de los evaluados para tratamiento profiláctico contra $O$. minus, y sugiere que la evidencia está construyendo para la efectividad de este producto generalmente contra el hongo ofiostomatoide. 